\title{
STUDY OF MINES WORKERS IN TERM OF OCCUPATIONAL HEALTH AND SAFETY: A CASE STUDY OF TRIBAL AREAS OF RAJASTHAN
}

\author{
Veena Dwivedi \\ Professor \& Head, School of Social Sciences, Jaipur National University, Jaipur, India \\ Email: veenamrd@yahoo.com
}

How to cite this paper:

Dwivedi, Veena (2021)

Study of Mines Workers in

Term of Occupational Health and Safety: A Case Study of Tribal Areas of Rajasthan, Journal of Global Resources, Vol. 07 (02)

DOI:

10.46587/JGR.2021.v07i02.013

Received: 28 March 2021

Reviewed: 25 April 2021

Revised: 17 May 2021

Final Accepted: 28 May 2021
Abstract: The study intends to find out the situation analysis of implementation of the occupational health problem, proper use of safety measures and awareness about the own health and rights. This study helps to find out reasons for not using the safety measure, not getting benefits from employers according to the basic needs. After this study an action plan was develop for further action. Occupational health and welfare issues related to small scale mines have been discussed and debated in various forums. Different agencies concerned with the health and welfare of workers have expressed their helplessness in doing anything significant due to complexities of issues involved and multiplicity of State and Central government agencies. Some of the important occupational health and welfare issues are discovered by this study which will be helpful to make action plan for this Ares women mines workers.

Keywords: Mine Workers, Tribal, Occupational Health, Safety Measures

OPEN O A C C ES S

Freely available Online www.isdesr.org 


\section{Introduction}

A Mines safety or employee safety refer to the protection of workers from the charger of industrial accidents. An accident, then as an unplanned, unschooled event in which an action or reaction of an offset, a substance. A person or a radiation results in personal in fury. Experience shows that even if no additional legislative initiatives can be taken by the Government due to practical constraints, a Policy Declaration acts as a framework for guidance and action and helps in promoting voluntary actions at different levels. In fact, the need for a coherent policy on OSH was internationally recognized as early as in 1981 as reflected in Article 2 of the ILO Convention.

\section{ABOUT THE AREAS}

Research Areas in Rajasthan

\begin{tabular}{|l|c|c|}
\hline Block & Total Village & Worst conditioned village up above 75 percent \\
\hline Gogunda & 152 & 28 \\
\hline Jhadol & 285 & 0 \\
\hline Kotra & 304 & 164 \\
\hline Kherwada & 257 & 126 \\
\hline Sarada & 188 & 123 \\
\hline Salumber & 250 & 32 \\
\hline Mavali & 152 & 20 \\
\hline Valabhnagar & 289 & 202 \\
\hline Dhariyavad & 251 & 6 \\
\hline Total & $\mathbf{2 4 0 6}$ & $\mathbf{8 6 0}$ \\
\hline
\end{tabular}

Source: Rajasthan Govt. websites, 2011

\section{Objectives of the Study}

1. To review the existing set up for occupational health and safety in the workplace

2. To know the occupational health problems among the women workers and their family members

3. To know about prevalence accident if any happened in work place.

4. To collect intimation about the safety measure which are used in mines?

5. To know attitude of management and women workers about the safety Measure.

6. To assess weaknesses of the existing set up and suggest ways to improve it;

7. To suggest ways to improve low cast occupational safety standards

\section{Hypothesis}

- Most of the women are associated as part time worker in mines, so that they are not getting any kind of health benefit as permanent workers.

- Most of the safety measures are not women friendly, so they are not using it for their safety.

- Women workers are not aware about the occupational health and use of safety measures, so they are not serious about their health.

- Most of the mine's owners are also not serious and sensitized about the human health issue, using safety measure only for show case

- Low-cost safety measures are not available neither workers nor mines owner are giving the human health issues on priority level.

- Problems related to growing mobility of worker population sand occurrence of new occupational diseases of various origins. 


\section{Sampling of Study}

First from Udaipur and Rajsambandh district two blocks named Badgav and Khamnore panchayat samiti of the Girawa, Pipad, Kaloda, Bhuritalei,Tulamaruwas, Lapada \& from Nathadawa, Acshibawadi, Unwas, Niracg Ghedachh \& Semal village were selected by using the lottery methods, than from each two block 5-5 villages were selected as per total strength of worker in mines workers in the village. The researcher take the study both an the execution and female worker for the universe of 179 employer were taken by using the census methods and the random sampling Methods. Focus group discussion was also done with respondent.

\section{Tools and Data Collection}

Both primary and secondary data were used for study. The major tool used to collect primary data was interview schedule, focus group discussion, Research visited units discussed and interviewed employer and also visited all the 10 villages and collected data with all the female labour family, household each village focus group discussion was held to verifying the existing data's \& others village information. Secondary data were collection from book, internet, and internal source of organization. From the different department and universities such as environment department, Sukhadia University, MSW collage, BN collage of Udaipur etc.

\section{Research Steps}

1. Data were collected by researcher with the support of Local NGOs, mates and MSW college students

2. Schedule was tested \& edited by researcher

3. Code looks filled along with data.

4. The data transferred to the master sheet with help of code book.

5. Tabulation and analysis were turned.

6. A comprehensive report of the research work was prepared.

\section{Personal \& Family Profile of The Mines Workers}

Most of the more than half mines worker was from age group of 15-30 years. The entire respondent was female \& among them three fourth 83 percent was from schedule tribe's family. All were Hindu. Educations wise most of them 96 percent where literate rest of the 4 percent respondent were illiterate. 89 percent of the respondent was married, only 4 percent were widow, regarding types of family 78 percent of the participants were living single family and 22 percent of the respondent were from joint family. Three fourth 76 percent of the respondent family income is below fifty thousand \& 22 percent of them have a family income fifty thousand to one lack.

\section{Working Areas \& Salary \& Satisfaction Level}

29- 30 percent of the respondent was working in Mantri \& Guruprit mines, whenever 11 percent of the respondent were working in Vadlia mines unwas, rests of the 1 to 5 percent of the respondent were working in mines nearby the Girawa And Rajsambandh Areas. More than half 66 percent respondent were in temporary job and 34 percent of the respondent were on permanent job. Most of them 85 percent of the respondent were working for their livelihood \& rest of the 3 percent of the working in mines for others purpose such as to take experience, for time pass, to support their relative or family members etc. More than half 58 percent of the mine's workers were working since 1 - 5 years, whenever 28 percent of them working for 5-10 years and others 4 percent to 6 percent were working for long time i.e., 10 to 20 years and rest of the 3 percent were working in mines more than 20 years. Three fourth 
96 percent of the respondent were working in mines 6-8 Hrs, rest of the were working for more than 8 hours, many times they giving extra duty

Same three fourth 79 percent of them were getting salary 50 rupees or less, others 21 percent getting more than 50 rupees as a salary., it was also found that 88 percent of the mine's workers were not getting any overtime salary, only few 12 percent were getting an overtime salary. when they were talk about the different in salary among them 93 percent said that there is no different in salary, whenever 6 percent said there is different in worker's salary \& 94 percent of the mine's workers were satisfied with present salary except few one.

\section{Use of Safety Measures, Its Type}

Three fourth 87 percent of the mine's workers were not using any kind of safety measures only 12 percent were using some safety measures those, who were using safety measures among them 82 percent were using Helmets and handlooms only 18 percent were using only helmets. Regarding the full safety in mine less than three fourth 73 percent were not getting any safety, but one third mines workers said that they were getting fully safety in mines, among them 60 percent were getting Helmet, Globes, Sue Socked, Mask etc., 33 percent of the mine workers were using the hankey, parade with own saree.

Table 01: Safety Tools Used During Work, Its Types

\begin{tabular}{|c|c|c|c|c|}
\hline$\#$ & Question & & Frequency & Percentage \\
\hline \multirow{4}{*}{1.} & \multirow{3}{*}{$\begin{array}{l}\text { What do you use safety tools } \\
\text { when you do work }\end{array}$} & Yes & 22 & 12.29 \\
\hline & & No & 155 & 86.59 \\
\hline & & Require & 2 & 1.12 \\
\hline & \multicolumn{2}{|l|}{ Total } & 179 & 100.00 \\
\hline \multirow{3}{*}{2.} & \multirow[b]{2}{*}{ If Yes, Whom } & Helmet & 4 & 18.18 \\
\hline & & Helmet and Handloom & 18 & 81.82 \\
\hline & \multicolumn{2}{|l|}{ Total } & 22 & 100.00 \\
\hline \multirow{4}{*}{3.} & \multirow{3}{*}{ full Safety in mines } & Yes & 46 & 25.70 \\
\hline & & No & 131 & 73.18 \\
\hline & & Regarded & 2 & 1.12 \\
\hline & \multicolumn{2}{|l|}{ Total } & 179 & 100.00 \\
\hline \multirow{5}{*}{4.} & \multirow{4}{*}{ If Yes, What kind } & $\begin{array}{l}\text { Helmet, Globes, Sue } \\
\text { Socks, Mask etc. }\end{array}$ & 25 & 59.52 \\
\hline & & Others & 14 & 33.33 \\
\hline & & No Women & 1 & 2.38 \\
\hline & & Give Doctor Service & 2 & 4.76 \\
\hline & \multicolumn{2}{|l|}{ Total } & 42 & 100.00 \\
\hline
\end{tabular}

Source: Field Survey

\section{The IIIness \& Medical Facility \& Treatment}

Only few mines' workers 5 percent were getting medical services by the doctor, women were not getting any such services. More than half 60 percent mines worker become ill during their working periods, Small number of the mine's worker were not aware about it. Those who were ill among them 31- 40 percent of the mine's workers feeling weaknesses \& 19 percent of them having an asthma and rest of 4- 6 percent having a T.B. and Psilosis diseases, those who were ill among them 80 percent were suffering since one to three years. Only 13 percent were suffering from one or more diseases few of them 3-4 percent suffer with disease since long time (6- 9 yrs. and above). It was also concluded that 86 percent of the mine's workers were taking their treatment themselves, rest of the 14 percent were getting treatment by owners. 
Less than half 49 percent of the mine's workers were getting the medicines facility whenever. 8 percent of them were not aware about it. More than half 55 percent mine worker said that their mine having a primary medicine facility, 37 were denied it and very few 8 percent respondent have no knowledge \& awareness about it. In brief It was also found that for last 5 years 34 percent of the mine's workers were affected by Asthma, 14-16 percent of the respondent were affected by Mouth ulcer \& Other's 16 percent were affected by others disease such as (body pain, skin disease etc.) Few one 3-4 percent of them was affected by Uterus related disease \& T.B., but 30 percent of the mine's workers have no any ideas in this regard. When they were asked that any women having a long-time illness most of the three fourth 81 percent mines workers were not aware about it, only 5 percent of them were aware about it. It was also concluded that More than half 56 percent of the mine's workers were taking home based treatment, 22 percent of them were taking treatment from P.H.C or any big hospital equally.

Table 02: Experiences Get for Treatment of Diseases, Medicines Facilities, First Aids Facilities, Trained Employers, Availability of Treatment Box

\begin{tabular}{|c|c|c|c|c|}
\hline$\#$ & Question & & Frequency & Percentage \\
\hline \multirow{4}{*}{1.} & \multirow{3}{*}{ Who provides treatment expenses? } & Owner & 12 & 13.95 \\
\hline & & Self & 74 & 86.05 \\
\hline & & Other & 0 & 0.00 \\
\hline & \multicolumn{2}{|l|}{ Total } & 86 & 100.00 \\
\hline \multirow{4}{*}{2.} & \multirow{3}{*}{ Availability of medicine benefit } & Yes & 87 & 48.60 \\
\hline & & No & 79 & 44.13 \\
\hline & & Not Know & 13 & 7.26 \\
\hline & \multicolumn{2}{|l|}{ Total } & 179 & 100.00 \\
\hline \multirow{4}{*}{3.} & \multirow{3}{*}{$\begin{array}{l}\text { Availability of primary medicine } \\
\text { benefit available }\end{array}$} & Yes & 99 & 55.31 \\
\hline & & No & 66 & 36.87 \\
\hline & & Not Know & 14 & 7.82 \\
\hline & \multicolumn{2}{|l|}{ Total } & 179 & 100.00 \\
\hline \multirow{4}{*}{4.} & \multirow{3}{*}{ trained employer in the mines } & Yes & 28 & 15.64 \\
\hline & & No & 64 & 35.75 \\
\hline & & Not Know & 87 & 48.60 \\
\hline & \multicolumn{2}{|l|}{ Total } & 179 & 100.00 \\
\hline \multirow{4}{*}{5.} & \multirow{3}{*}{$\begin{array}{l}\text { knowledge of treatment box rules } \\
\text { in the mine }\end{array}$} & Yes & 28 & 15.64 \\
\hline & & No & 65 & 36.31 \\
\hline & & Not know & 86 & 48.04 \\
\hline & \multicolumn{2}{|l|}{ Total } & 179 & 100.00 \\
\hline
\end{tabular}

Source: Field Survey

\section{Trained Medical Staff/ Diseases and about the Health \& Others Welfare Programme}

Less than half respondent doesn't know about the trained staff, 36 percent of them said that there is no any trained staff who were having a knowledge about the medicines and medical kit use, few of them 16 percent mines female worker told they were getting a treatment by trained staff. Most probably same quantity of the respondent was aware about the mine's treatment box rules. More than half 65 percent of the mine's workers were not aware about the Health Programme running in the mines. Those were aware about it among them most of 74 percent aware about the Drinking water facilities related proramme, 23 percent were known about the medicine related facilities, very few were aware about the Security, compensation, Health Safety \& Health Van etc. more than half 54 percent of the mine's owners were providing Drinking water and 32 percent were getting the medicine related facility. Others very few were getting security, gift, compensation etc. 


\section{The Accident/Treatment, Safety Zone}

More than half 65 percent of the mine's workers were not aware about the accident occurs in mines during the work. All were injured during their duty. Those who injured among them 60 got injury in foot after that 39 injured in hand, very few of them were got injury in head. 69 mines workers of them did treatment themselves its less than half 31 percent of them were provided treatment by the mines. 85 percent of them have not got any expenses for treatment by the owner. Those who got expenses among them 67 percent mines workers got less than 200 rupees, 22 percent of them were got more than 300 rupees rest of the half 11 percent of them got 200 to 300 rupees for their treatment. 98 percent mines workers got road accident reason is a Road is difficult and overweight safety. Most of the 94 percent of them said that no any accident occurs within last three year. So, we can say that accidents are common phenomena in the mines. These accidents mostly take places due to the lack of proper training on job and the inadequate safety measures adopted by the workers. Accident may include death, fractures, sickness etc. some of these eventualities can be avoided by the use of safety objects such as Helmet, Globes, Sue Socked, Mask etc. these things are not provided to most of the workers

\section{The Safety Measures Facility}

Very few workers were aware about the ambulance facility in the mines. It was also found that 81-88 percent of the mine's workers said that mines owner is not giving them helmet \& Globs, only $6-15$ percent of them are getting the helmet \& Globs, because they are working in dangerous zone. Among them more than half 55 percent were not using theses safety tools, only few 6 percent were using an any safety tools. The safety measures for the workers both the men and women are comparatively insufficient and improper. Lack of information and awareness among the lobours are the prime reason for this kind of behaviors. Secondly the mine owners or the contractors make use of the ignorance of the workers about the safety measures.

\section{The Training Programme}

More than half 59 percent mines workers were not aware about the training programme, 39 percent of them said they were not provided any king of training during their work period by the owner. those who few workers get training half of them were get it by their supervisor or trainer working in mine.

\section{Safety Facilities \& Its Impact}

As per most of the 80 percent of the mines workers there is no any insurance facility available in the mines. Less than half 24 percent of mines worker were about the emergency alarm, whenever 44 percent of them said that there is no any emergency alarm availability in the mines. Regarding the labour break rules in mines only 36 percent of the mine's workers know about it. Most of the 95 percent mines workers were don't know the impact of safety tools, only 4 percent of them said if they are using any safety tools it's increasing the mines product. Most of the 93 percent of them said that safety tools preventing the accident. Though the mines run some kind of health programme and its benefits they are inadequate. The programmes benefit only a few. Majority of the labours agree that there were accidents during the last three years and the reasons for the accidents also known to all. But the prevention methods used by concerned people are not sufficient. Many of the facilities available in the mines are also are not used properly. Due to the lack of proper training even the available emergency tools are not effectively used. 
Table 03: Facilities in Mines, Ambulance, Helmet, Globs, and Use of All Safety Tools

\begin{tabular}{|c|c|c|c|c|c|}
\hline \# & \multicolumn{3}{|l|}{ Question } & Frequency & Percentage \\
\hline \multirow{4}{*}{1.} & \multirow{3}{*}{\multicolumn{2}{|c|}{$\begin{array}{l}\text { What in your mines there is } \\
\text { ambulance benefit }\end{array}$}} & Yes & 11 & 6.15 \\
\hline & & & No & 134 & 74.86 \\
\hline & & & Not Knows & 34 & 18.99 \\
\hline & \multicolumn{3}{|l|}{ Total } & 179 & 100.00 \\
\hline \multirow{4}{*}{2.} & \multirow{3}{*}{\multicolumn{2}{|c|}{ What your mines give you helmet }} & Yes & 28 & 15.64 \\
\hline & & & No & 145 & 81.01 \\
\hline & & & not Regarded & 6 & 3.35 \\
\hline & \multicolumn{3}{|l|}{ Total } & 179 & 100.00 \\
\hline \multirow{4}{*}{3.} & \multirow{3}{*}{\multicolumn{2}{|c|}{ What your mines give you Globs }} & Yes & 11 & 6.15 \\
\hline & & & No & 158 & 88.27 \\
\hline & & & No Regarded & 10 & 5.59 \\
\hline & \multicolumn{3}{|l|}{ Total } & 179 & 100.00 \\
\hline \multirow{4}{*}{4.} & \multirow{3}{*}{\multicolumn{2}{|c|}{ What you use all safety tools }} & Yes & 10 & 5.59 \\
\hline & & & No & 99 & 55.31 \\
\hline & & & Not Regarded & 70 & 39.11 \\
\hline & \multicolumn{3}{|l|}{ Total } & 179 & 100.00 \\
\hline \multirow{6}{*}{5.} & \multirow{5}{*}{ If No why } & \multicolumn{2}{|l|}{ Not like } & 1 & 1.01 \\
\hline & & \multicolumn{2}{|l|}{ Go given* } & 44 & 44.44 \\
\hline & & \multicolumn{2}{|c|}{ others Reason, work suffering } & 1 & 1.01 \\
\hline & & \multicolumn{2}{|c|}{$\begin{array}{l}\text { when checking then give some } \\
\text { tools }\end{array}$} & 51 & 51.52 \\
\hline & & \multicolumn{2}{|c|}{$\begin{array}{l}\text { only men are getting it not } \\
\text { women }\end{array}$} & 2 & 2.02 \\
\hline & \multicolumn{3}{|l|}{ Total } & 99 & 100.00 \\
\hline
\end{tabular}

Source: Field Survey

\section{The Safety Days and Safety Committee, Union Members}

Table shows that 82 percent of the respondent said that there is no any safety committee in mines. Most of them 77 percent were not know about any safety law in mines, neither know about the safety law details, those who don't know about it among them more than half 53 have a Lack of awareness 16- 23 percent of them said they don't get any training or there is no any policy about it. 91 percent of the respondent were not aware about the celebration of the national safety day except 9 percent of the respondent neither they were aware about its celebration eject date.

Table 04: The Safety Committee, Safety Law, Awareness About the Safety Law

\begin{tabular}{|c|c|c|c|c|}
\hline \# & Question & & Frequency & Percentage \\
\hline \multirow{4}{*}{1.} & \multirow{3}{*}{ About the safety committee in mines } & Yes & 21 & 11.73 \\
\hline & & No & 146 & 81.56 \\
\hline & & Not Know & 12 & 6.70 \\
\hline & Total & & 179 & 100.00 \\
\hline \multirow{4}{*}{2.} & \multirow{3}{*}{ About the safety law in mines } & Yes & 7 & 3.91 \\
\hline & & No & 34 & 18.99 \\
\hline & & Not know & 138 & 77.09 \\
\hline & Total & & 179 & 100.00 \\
\hline \multirow{3}{*}{3.} & \multirow{2}{*}{ What you know this safety law } & Yes & 0 & 0.00 \\
\hline & & No & 179 & 100.00 \\
\hline & Total & & 179 & 100.00 \\
\hline \multirow{6}{*}{4.} & \multirow{5}{*}{ if you do not know what any reason } & Lack of awareness & 142 & 52.79 \\
\hline & & Lack of Training & 61 & 22.68 \\
\hline & & lack of Policy & 24 & 8.92 \\
\hline & & Don't know & 42 & 15.61 \\
\hline & & other & 0 & 0.00 \\
\hline & \multicolumn{2}{|l|}{ Total } & 269 & 100.00 \\
\hline
\end{tabular}

Source: Field Survey 
Regarding the union members in the mines more than half 70 percent of the respondent feel need to have a union member in mines, rest of the 40 percent of the respondent don't know about this. Again, 57 percent respondent need safety laws in mines. About 60 percent of them said that no safety and emergency staff training given by mines, whenever 37 percent of them were not aware in this regard. Regarding the union members in the mines more than half 70 percent of the respondent feels urgent need to have a union member in mines. So, we can say that 40 percent mines workers were not give any response in this matter. More than half 60 percent of them said that no safety and emergency staff training given by mines, when they were asked about the safety officer select in your mines same number of the mine's workers less than one third 23 percent of them have answer is yes or no, more than half 54 percent have no any answer in this regard.

\section{Change in Safety Methods}

Most of the 95 percent of the mine's workers want to change in safety methods expect 4 percent of the mine's worker, very few only less than one percent of them don't reply in this regard. Those who want not clear about the kind of change they need, but some of them $9-$ 17 percent were need Helmet, Socks, increase salary, want Full Safety, compensation and the permanent job, etc., very few of the mine workers less than two percent of them want Safety officer, Safety rules, good medical facility in the mines they said that women should Give Fully safety less Weight to pick up. Regarding the change in present safety rules only 21 percent of the respondent need safety tools, 15 percent of them want to increase salary, perfect safety and 10 percent of the mine's workers need rest room. Others very few 5-8 percent need Insurance, Helmet, sue Globs and Ambulance, 1-3 percent of the respondent need Toilet, less working hours limits, Permanent Jobs, Medicine and to make safety rules in mines.

\section{Suggestions}

1. Evaluation of safety rules time to time.

2. Public awareness about safety, health and environment should be created by way of training and awareness campaigns by using IEC Information, Education \& communication materials on personal Health, hygiene \& sanitation, use and benefits of safety kits.

3. Participation of organizations specialized in the field of safety; health

4. All mines should include a statement on status of occupational safety and health in their Annual Reports.

5. Mine's safety rules should be put in to practice very strictly and the safety tools should be made available invariably to all the workers.

6. Provision of the workers Insurance, emergency alarm, labour break rules in mines etc. should be made known to all the workers through awareness programmes and trainings.

7. The safety laws should be implemented and awareness about the safety law must be created among the workers for this purpose a safety committee can be formed.

8. Emergency safety tools should be provided to all the workers and training about the use of the tools also must be provided. There should be trained safety officer available in every work sites.

9. Celebration of the national safety day is a good circumstance to make aware of the importance of the safety rules and its importance. 
10. Survey of mine accidents and development of mine safety information systems (SOMA) should be enhanced Science \& Technology support, human resource development \& development of mine rescue services (S\&T);

11. Need training in the areas which have been selected after much scrutiny and are described below:

- Chemical Safety and Major Accident Hazards Control.

- Behavioral aspects of safety and health management.

- Ergonomic considerations in safety and health.

- Management of information on safety and health.

- To make chief and affordable safety kits for women

\section{Conclusion}

This entire study is very useful for those who are associated with mines worker and occupational health of mines workers. Most of the 95 percent of the mine's workers want to change in safety methods. Those who want not clear about the kind of change they need, but some of them 9-17 percent were need Helmet, Socks, Increase salary, want Full Safety, compensation and the permanent job, etc, they need training on various field such as chemical safety, behavioral aspect, management and low-cost safety.

\section{References}

1. Grimaldi V. John. (1989). Safety management and there All India Travelers Book Seller, New Delhi.

2. TN Chhalare, Human Resource Management (2007). Bhanpat Real, New Delhi

3. Mahappa Arun" Industrial Relation (1965). Tata Megrew Hill Publishers, New Delhi

4. Singh K Shclerler (1998) Safety and Risk Management Milted Publication, New Delhi.

5. http://www.minesandcommunities.org/Action/press785.htm

6. http://www.minesandcommunities.org/Action/press785.htm) 